\title{
Research and Practice of Inquiry Teaching of Management Information System Based on Network Learning Space
}

\author{
Jiaming Zhong ${ }^{1, \text { a }}$, Xia Ou yang ${ }^{1, b^{*}}$, Jialu Zhang ${ }^{1, c}$ and Xiaogang Tang ${ }^{1, d}$ \\ ${ }^{1}$ Xiangnan University, Chenzhou, Hunan, China, 423000 \\ ajmzhongcn@163.com,byxcngg@163.com,xnxypgbzy@163.com, ,kycxk1@163.com \\ ${ }^{*}$ corresponding author
}

Keywords: Network learning space; Management information system; Inquiry teaching; Inquiry learning

\begin{abstract}
According to the characteristics of Management Information System, the inquiring teaching mode based on the network learning space is constructed. Including the teaching resources development, class community construction and case guidance teaching situation creation; Role orientation of teachers and students. The effective integration of individual teaching strategies, group teaching strategies and classroom teaching strategies; Before class, class and after class, such as the improvement of teaching links, etc. This paper puts forward the formative evaluation and the summary evaluation method of the inquiry teaching of Management Information System based on the network learning space.
\end{abstract}

\section{Introduction}

Management Information System is a very important specialized fundamental course for majors of economics and management, and the curriculum is theoretical, practical, and comprehensive with large capacity of knowledge. The teaching content are abstract and difficult for students to understand and master, also due to the lack of management experience, lack of understanding on the organization of the actual business process and information process, understanding of the difficulties of the theory of management information system. However, In the current teaching. The teaching method is dull. The cramming method of teaching phenomenon is so serious, ignoring students' learning initiative, enthusiasm and creativity. Teaching evaluation form is single, lack of students' practice ability and innovation ability evaluation. Therefore, strengthening the teaching reform, to find the cultivation of students' comprehensive quality, enhance the overall quality of talent training of ways to cultivate high-quality talents, is faced in the current teaching of an important and urgent problem.

\section{Inquiry Teaching Related Concepts}

The Connotation of Inquiry Teaching. Inquiry teaching is that students under the guidance of teachers, scientific research course related topics from the initiative to found the problem, problem solving, knowledge so as to achieve the acquisition and application, and cultivating the students' innovative spirit and ability in knowledge acquisition and application; Inquiry teaching is the teachers and students to the activities of knowledge learning process, but also teachers and students about issues of common methods to carry out the determination, the content selection and to solve the problem of mutual cooperation and exchanges in the process of practice.

The Basic Characteristics of Inquiry Teaching. (1) Openness: The open nature of inquiry style includes teaching content, teaching process and the openness of teaching organization.

(2)Research character: Inquiry based teaching is a teaching, which is based on the research of teaching and scientific research under the guidance of teachers.

(3)Independence: Inquiry teaching process is essentially a process of self-exploration developed and implemented with students' existing knowledge and experience. From the formation of problems, gathering and collecting of research materials to writing research reports and 
demonstrating research results, students can make the decision according to their own interests and hobbies while teachers only serve as the guider and tutor.

(4)Practicality: Inquiry teaching emphasizes the connection between theory and practice, and pays attention to the close combination of theory with the development of social economy and the actual life.

Principles of Inquiry Teaching. (1)Combination of teaching and research: One is the combination of teaching content and research content; two is the teaching activities in the form of research and development; three is the active participation of students in research activities.

(2) Combination of theory and Practice: To guide college students to pay attention to the problems of social and real life, to actively participate in social practice, to cultivate the innovative spirit and practical ability of College students.

(3)Combination of class and outside class: Combine the first class and the second class, coordinate with each other, and play a role together.

\section{Inquiry Teaching Mode of "Management Information System" Based on Network Learning Space.}

Teaching Situation Creation. In the traditional class teaching, teachers and students, between students can conduct face-to-face communication, and teachers can effectively control the teaching process, but also can help students to adjust the learning process. Therefore, making full use of the advantages of the traditional classroom teaching and space teaching to create teaching situation.

(1) Class Community Construction: First of all, teachers and students in the University City in the world registered name of account, the teachers and students to add each other as friends, then the teacher use class management function, can establish the courses they teach classes, teachers can online homework, homework, correcting homework, homework management. In this way, the teachers and students construct the network

(2) Development of Teaching Resources: The development of teaching resources for the systematic digitization, including: Curriculum guide (study guide, lecture notes and the teaching courseware, electronic lesson plans, case base, paper, exercise library, teaching video), practice teaching (experimental program, experimental instruction, students' experimental report, curriculum design, design results), knowledge expansion (reading, network resources, self-study materials). Then, upload the development of good teaching resources to the network learning space.

(3) Case Guide: Case guidance through the course, before and after class and so on teaching process of the whole process. Teachers carefully select a typical case of a representative, which can reflect the reality in the new trend and new theory, including classic success stories, close to the students to live and study of cases and high grade students of outstanding design works etc. Such as educational administration management information system, student dormitory management information system, campus card system, supermarket management information system is close to the students and the ability to solve practical problems of typical cases. Through the integration of the case and the theoretical knowledge, and design the case. The system feasibility study, system analysis, system design, system implementation and system operation and maintenance of the management information systems is decomposed into each of the five stages. In the teaching process to the student, teacher led, allow students to participate in various stages of development of the system to cultivate students' initiative to analyze and solve problems. For example, students can use the system analysis of the teaching system to simulate the system analyst, the use of management information system analysis tool to complete the investigation and analysis of enterprise's personnel management system. Teaching system design this chapter, the student can simulate for the system design personnel, the use of the system design method of the system, the system code, data storage, information flow design. In the teaching system to implement this chapter. Firstly, the implementation process of the example system by the teacher demonstration to let the students from the rational and perceptual two party to the teaching content to master and then set up the project team to complete the development of a small system.

Students through their own thinking and talking to each other, put forward their own ideas. Then, 
with a problem, combined with the case, for to learn and use in developing methods and tools, and gradually complete the experiment content, in order to promote the students, work in pairs to system division, flow chart, data flow diagram, data dictionary, code design, database design, etc. knowledge understanding.

Role Orientation of Teachers and Students. Based on the inquiry teaching of network space, the role of teachers and students change. Teaching activities, teachers are the developer of teaching resources, teaching activities of the designers, organizers and collaborators, the guidance of student learning, teacher's work focused on how to stimulate students to think and explore. While students from passive knowledge recipients into the master of learning, active exploration, active interaction, collaboration and sharing, to enhance their ability to explore.

Effective Integration of Teaching Strategies. Based on the network space, the inquiry teaching will integrate the individual teaching strategies, the group teaching strategies and the class teaching strategies effectively. Individualized teaching strategies emphasize students' individual differences, focusing on students' independent inquiry, and the students' self-control, adjustment and evaluation. Group collaborative learning, to stimulate the students' desire for knowledge, fully mobilize the enthusiasm of the students learning enthusiasm, and at the same time, but also cultivate students' interpersonal skills, team spirit and cooperation ability, and achieve common goals. The class teaching strategy mainly takes the special subject teaching method so that the students can grasp the curriculum content system of the management information system from the whole.

Perfect Teaching Link. Using the network space rich interactive mode and digital teaching resources, can be very good to improve the class before and after class teaching link.

(1) Preparation before Class: By introducing the case of each chapter's problems, driven by problems and through cyberspace, students can view the teaching resources, clarify teaching objectives and requirements, and watch the video and teaching courseware for consolidation exercises and tests. When there are problems between teachers and students or among students, they can message each other and discuss with each other, and finally summarize the knowledge points, difficult problems and learning experience. Teachers upload digital resources to the network, release teaching information, constantly pay close attention to the students' learning dynamic, situation and difficulties in practice, combined with the key points and difficult points of teaching content, further the design of classroom teaching activities.

(2) Digest Knowledge in Class: Combined with knowledge of case knowledge internalization, teachers in the classroom organization, to give full play to students' learning initiative, and the solution actual problem the cultivation of students' independent thinking ability are pointed out, to enable students to effectively the internalization of knowledge, system to construct their own knowledge and ability. Teachers in the classroom before class design student grouping and allocation to explore the issue. Each of the students to actively participate in inquiry activities, express their views, share their learning experiences, by communication and cooperation together to complete learning goal, cultivate teamwork and collaboration, rely on the collective explore and solve problems, implement research learning.

(3) Learn More Knowledge after Class: Through the pre class preparation, class in internalization, students have a preliminary understanding of the knowledge of the contents of the chapters, but still need to receive training in the process of solving practical problems through in order to achieve real grasp of knowledge and skills. For each knowledge point, design skills development practice tasks, students in the after-school practice arrangement, promote the deepening and sublimation of knowledge and skills.

Students in social research and practice, to a production and management organization structure diagram, list of business functions, organization / business matrix, business flow chart, data flow diagrams, entity / relationship diagrams, U / C matrix, chart, HIPO, analysis and design tool, clear surface business information flow characteristics, and construct the corresponding information system. In order to acquire the method and steps of the system model, it is able to carry on the demand analysis, the database design, the information system development and the data processing ability. 


\section{Research on the "Management Information System" Based on the Network Learning Space.}

Teaching activity is the central work of school education, and the teaching effect has a direct impact on the growth of students. The teaching effect evaluation of the whole system includes formative evaluation and summary evaluation. Summary evaluation of the use of the final examination papers, accounting for $50 \%$ of the total score. Formative assessment includes 4 Level II indicators as shown in Table 1 .

Table 1 Space teaching formative evaluation index system.

\begin{tabular}{|c|c|c|c|}
\hline \multicolumn{2}{|c|}{ First Order Index } & \multicolumn{2}{|l|}{ Second Order Index } \\
\hline Index Item & Weight & Index Item & Weight \\
\hline \multirow{4}{*}{$\begin{array}{l}\text { Learning } \\
\text { Attitude }\end{array}$} & \multirow{4}{*}{0.2} & Learning purpose is clear, most of the time into effective learning & 0.05 \\
\hline & & Positive Emotional Involvement & 0.05 \\
\hline & & Learning Initiative & 0.05 \\
\hline & & A Sense of Achievement in Learning & 0.05 \\
\hline \multirow{4}{*}{$\begin{array}{l}\text { Learning } \\
\text { Process }\end{array}$} & \multirow{4}{*}{0.2} & Often discuss the course content in space & 0.05 \\
\hline & & Before class will preview the teaching resources & 0.05 \\
\hline & & Often share learning experience & 0.05 \\
\hline & & Often watch space resources after class & 0.05 \\
\hline \multirow{4}{*}{$\begin{array}{l}\text { Communication } \\
\text { and Interaction }\end{array}$} & \multirow{4}{*}{0.25} & Communication and communication with teachers. & 0.0625 \\
\hline & & All through the space to submit work & 0.0625 \\
\hline & & Often use the space to express learning experience & 0.0625 \\
\hline & & Discuss the number of learning problems with your classmates & 0.0625 \\
\hline \multirow{5}{*}{ Learning Effect } & \multirow{5}{*}{0.35} & Stimulate further interest in learning & 0.07 \\
\hline & & Expand the knowledge & 0.07 \\
\hline & & $\begin{array}{l}\text { In accordance with the resources provided by the teachers to carry } \\
\text { out autonomous learning }\end{array}$ & 0.07 \\
\hline & & The ability to obtain, express and process information is improved & 0.07 \\
\hline & & Teamwork, collaboration capabilities are greatly & 0.07 \\
\hline
\end{tabular}

\section{Conclusion}

The inquiry teaching based on the network learning space can promote the reform of teaching mode, effectively play the leading role of teachers and students, and has good application value.

\section{Acknowledgement}

2013 Hunan Province Colleges and universities teaching reform research project (based on cyberspace "management information system" inquiry teaching research and practice), Hunan Province five years education planning project (Undergraduate Colleges and Universities Based on network learning space of teaching mode study (project number XJK013BGD053), Xiangnan college education reform project (research study in the teaching of Management Information System application) and Xiangnan College $12^{\text {th }}$ key disciplines funded this study.

\section{References}

[1] Y.L.Zheng, L.Y.Li and Y.N.Wang:Modern Remote Education,(2010)No.3,p.50.

[2] Q.Lu: E-education Research, (2013)No,8,p.91.

[3] R.H.Huang: Computer Supported Collaborative Learning (People's education press, China 2013).

[4] J.F.Ren, K.D.Li: E-education Research, (2004) No.8, p.3.

[5] Ch.S.Ren: Inquiry Learning and Self-construction of Students' Knowledge (Educational Science Publishing,Beijing 2005).

[6] Zh.L.Wu, L.Zhao: China Educational Technology, (2014) No.4, p.121. 
[7] X.L.Zhong,Sh.Q. Song and L.ZH.Jiao: Open Education Research, (2013)No.2,p.58.

[8] H.Wang, W.Zhao and L.H.Sun, etc: Modern Educational Technology, (2013) No.8, p.5.

[9] J.L.Zhang: China Remote Education, (2013) No.10, p.59.

[10]R.Wang, Q.H.Bai and G.F.Zhang: Modern Educational Technology, Vol.13 (2009) No.19, p.256.

[11]Sh.Q.Yu, J.Wu: Information Technology and Curriculum Integration Teaching Mode and Method in the Network Age (Shanghai Education Press, China 2005). 